\title{
Peningkatan Soft Skill Siswa Melalui Pembuatan Sabun Ekstrak Kulit Buah Naga Merah (Hylocereus polyrhizus) di MA. Habiburrahman Jatian-Pakusari Jember
}

\author{
Hadi Barru Hakam Fajar Siddiq*, Agnis Pondinekaria Aditama \\ Akademi Farmasi Jember \\ *Corresponding author, Email: hakamfajar@gmail.com
}

\begin{abstract}
ABSTRAK
Kegiatan pengabdian kepada masyarakat yang dilakukan oleh dosen dari Program Studi Diploma III Farmasi Akademi Farmasi Jember yang dilaksanakan pada bulan Maret 2018, bertempat di MA. Habiburrahman Desa Jatian, Pakusari Jember ini memberikan manfaat bagi siswa dalam hal meningkatkan keterampilan melalui sabun ektrak buah naga. MA. Habiburrahman merupakan salah satu lembaga pendidikan tingkat atas di bawah Departemen Agama yang berada di Desa Jatian, Kecamatan Pakusari Jember. MA. Habibirrahman juga memiliki lembaga pendidikan agama yaitu Pondok Pesantren Habibirrahman. Hampir $70 \%$ siswa MA. Habiburrahman adalah santri pondok. Hasil kegiatan menunjukkan bahwa MA Habiburrahaman tidak terdapat kurkulum yang fokus dalam keterampiran siswa. Oleh karena itu, program ini memberikan banyak manfaat kepada siswa untuk menambah softskill di bidang teknologi. Selain itu, program ini sangat diminati oleh seluruh siswa.
\end{abstract}

Kata Kunci: Pengabdian kepada masyarakat, keterampilan, sabun, buah naga merah

\begin{abstract}
Community service activities undertaken by lecturers from Pharmacy Diploma III Program of Pharmacy Academy of Jember held on March, 2018, held at MA. Habiburrahman Jatian, Pakusari Jember provides benefits for students in improving students skill through soap red dragon fruit extract. MA. Habiburrahman was senior high school under the Ministry of Religious Affairs located in Jatian-Pakusari-Jember. MA. Habibirrahman also has a religious education institution that is Pondok Pesantren Habibirrahman. Nearly 70\% of students of MA. Habiburrahman were santri. The results show that MA Habiburrahaman does not have a curculum that focuses on the attachment of students. Therefore, this program provides many benefits to students to add soft skills in the field of technology. In addition, this program is in great demand by all students.
\end{abstract}

Keywords: community servive, soft skill, soap, red dragon fruit

\section{PENDAHULUAN}

MA. Habiburrahman merupakan salah satu lembaga pendidikan tingkat atas di bawah Departemen Agama yang berada di Desa Jatian, Kecamatan Pakusari Jember. MTs. dan MA. Habibirrahman juga memiliki lembaga pendidikan agama yaitu Pondok Pesantren Habibirrahman. Hampir $90 \%$ siswa MA. Habiburrahman adalah santri pondok. Siswa ditingkat MA. memiliki rentang usia 15-17 tahun yang tergolong usia remaja. Hurlock (1973) memberi batasan masa remaja berdasarkan usia kronologis, yaitu antara 13 hingga 18 tahun. Lebih lanjut Thornburgh (1982) membagi usia remaja menjadi tiga kelompok, yaitu: 1) remaja awal antara 11 
hingga 13 tahun, 2) remaja pertengahan antara 14 hingga 16 tahun,dan 3) remaja akhir antara 17 hingga 19 tahun.

Banyak diantara siswa dari MA. Habiburrahman setelah lulus sekolah, mereka tidak melanjutkan ke tingkat pendidikan yang lebih tinggi dan cenderung menjadi pekerja kasar. Hal ini dikarenakan ketarampilan mereka masih rendah. Selain itu, kurangnya informasi dari pihak luar maupun kerjasama sekolah dengan pihak luar tentang upaya peningkatan soft skill siswa, sehingga mereka yang tidak melanjutkan pendidikan lebih tinggi setelah lulus belum mampu berkarya di masyarakat.

Salah satu faktor kondisi siswa MA. Habibusrrahman adalah kondisi latar belakang ekonomi dan keluarga Siswa MA. Habiburrahman saat ini sebagian besar menggambarkan kelompok status ekonomi menengah ke bawah dengan latar belakang pendidikan orang tua juga rendah. Hal ini yang menyebabkan tingkat pemahaman siswi tentang kesehatan masih rendah. Selain itu, di lingkungan Pondok Pesantren, mereka terbiasa mandi, tidur dan menggunakan perlengkapan sehari-hari secara bersama-sama dan bergantian, sehingga dapat membuat para siswi/santri kurang menjaga kebersihan dan kesehatan.

Di lain pihak, buah naga merah (Hylocereus polyrhizus) merupakan salah satu buah yang sudah mulai banyak di tanam di daerah Jember dan menjadi salah satu komoditas di Jember. Sebagai salah satu icon Kabupaten Jember, buah naga saat ini sudah menjadi kebanggaan masyarakat Jember. Budidaya buah naga terus mengalami peningkatan, hal ini dapat dilihat bahwa budidaya buah naga pada tahun 2009 seluas 7 ha dan saat ini sudah mencapai 12 ha. Hal yang menarik pada buah naga adalah manfaat dari kulitnya. Selama ini kulit buah naga jarang dimanfaatkan dan lebih sering menjadi limbah. Sebenarnya kulit buah naga dapat bermanfaat dalam produksi pangan maupun industri seperti pewarna alami makanan dan minuman. Selain itu, dalam industri kulit buah naga dapat dijadikan bahan dasar pembuatan kosmetik, salah satunya adalah sabun.

Buah naga berdaging merah adalah buah yang paling disukai dibandingkan buah naga lainnya karena rasanya yang manis dan warna daging buahnya merah dan menarik (Satria, 2011). Kulit buah naga mengandung vitamin C, vitamin E, vitamin A, alkaloid, terpenoid, flavonoid, tiamin, niasin, piridoksin, kobalamin, fenolik, karoten, dan fitoalbumin (Jaafar et al., 2009). Menurut penelitian Wu et al., (2006) keunggulan dari kulit buah naga yaitu kaya polifenol dan merupakan sumber antioksidan. Selain itu aktivitas antioksidan pada kulit buah naga lebih besar dibandingkan aktivitas antioksidan pada daging buahnya, sehingga berpotensi untuk dikembangkan menjadi sumber antioksidan alami yang dapat bermanfaat bagi kesehatan.

Adanya aktivitas antioksidan dalam kulit buah naga merah inilah yang dalam segi ekonomis dapat dimanfaatkan, yaitu sebagai bahan baku dalam pembuatan sabun. Dengan Demikian, memberikan informasi dan peluang bagi masyarakat khususnya siswa MA. Habiburrahman untuk belajar membuat olahan kulit buah naga menjadi produk sabun yang dapat bermanfaat untuk mereka dan dapat dijadikan sebagai peluang usaha pada saat mereka telah lulus.

\section{METODE PELAKSANAAN}

\section{A. Kerangka Pemecahan Masalah}

Kerangka berpikir untuk memecahkan masalah kegiatan ini digambarkan seperti pada gambar 1 . Dari permasalahan yang muncul disusun alternatife untuk memecahkan masalah. Selanjutnya dari berbagai alternative, dipilih alternatif yang paling mungkin dilaksanakan. 


\section{B. Realisasi Pemecahan Masalah \\ 1. Ceramah dan Diskusi}

Ceramah dan diskusi dilakukan untuk memberikan pemahaman siswa tentang hidup bersih dan sehat serta bagaimana mengolah bahan-bahan alam menjadi produk olahan yang dapat bermanfaat untuk kesehatan dan bernilai ekonomis.

\section{Praktek}

Kegiatan ini merupakan lanjutan dari metode ceramah dan diskusi yang secara khusus bertujuan untuk meningkatkan ketrampilan soft skill siswa MA. Habiburrahman tentang pengolahan kulit buah naga merah (Hylocereus polyrhizus) dan pembuatan sabun dari ektrak kulit buah naga merah (Hylocereus polyrhizus).

\section{Keterkaitan}

Kegiatan pengabdian kepada masayarakat melalui program Iptek bagi Masyarakat ini melibatkan instansi Akademi Farmasi Jember dan MA. Habiburrahman Desa Jatian Pakusari Jember. Kedua instansi yang terlibat ini mendapat keuntungan secara bersama-sama, antara lain: 1. MA. Habiburrahman Desa Jatian Pakusari Jember sebagai tempat pelaksanaan kegiatan akan menyediakan SDM yaitu siswa yang akan dilatih. Dengan demikian, siswa MA. Habiburrahman akan memeperoleh manfaat dalam hal peningkatan ketrampilan (soft skill) siswa,

2. Akademi Farmasi Jember melalui lembaga Penelitian dan Pengabdian kepada Masyarakat berperan menyediakan dana, sehingga mendukung pelaksanaan dharma ketiga dari tri Dharma Perguruan Tinggi.

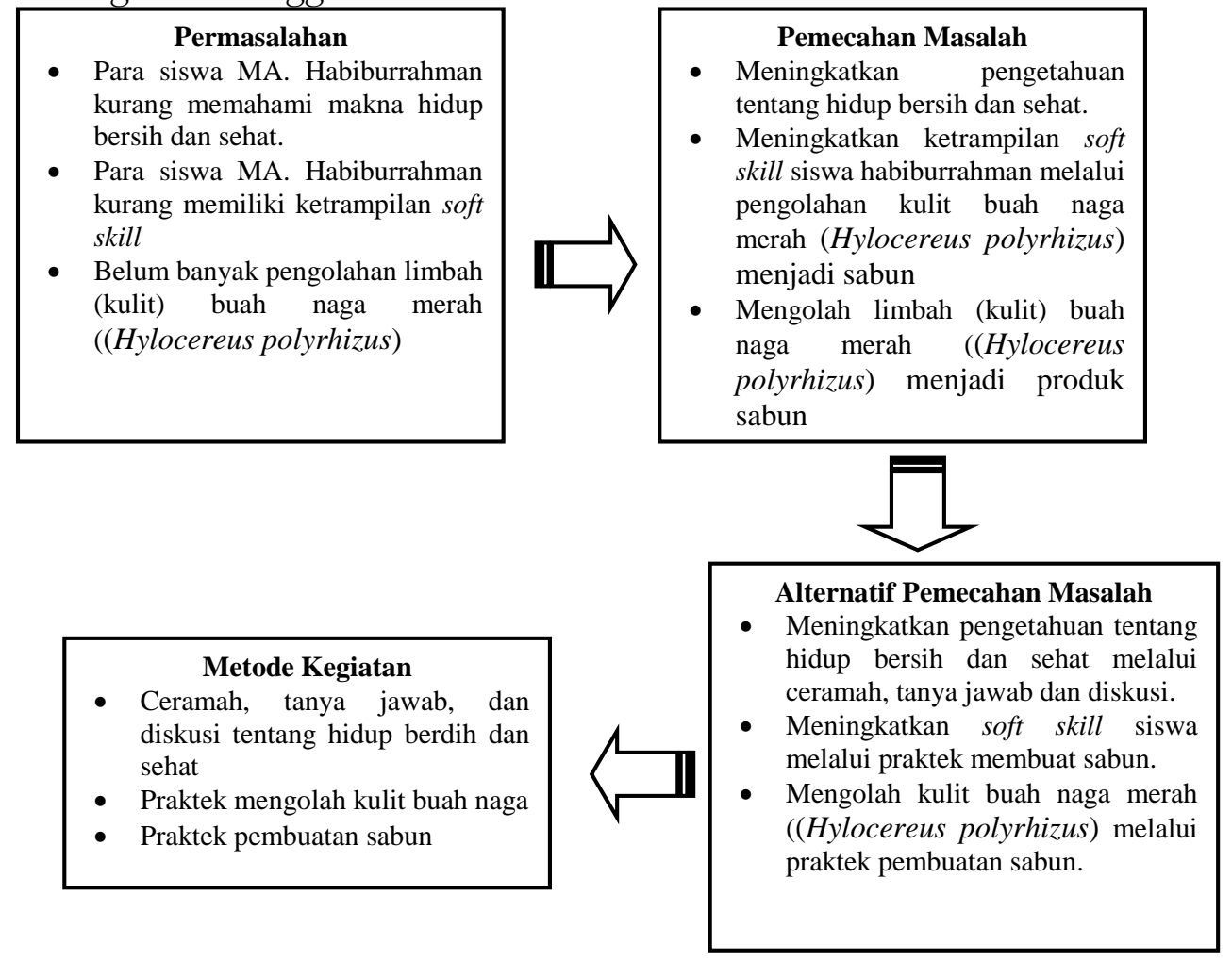

Gambar l. Bagan Skematis Metode Pemecahan Masalah 


\section{Khalayak Sasaran}

Khalayak yang dijadikan sasaran kegiatan ini adalah siswa MA. Habiburrahman Desa Jatian Pakusari Jember. Keterlibatan mereka dalam kegiatan pengabdian kepada masyarakat ini dapat dilihat pada table 1 .

\begin{tabular}{|c|c|c|}
\hline Khalayak & Kegiatan & Sasaran \\
\hline $\begin{array}{l}\text { Siswa MA. Habiburrahman Desa } \\
\text { Jatian Pakusari Jember }\end{array}$ & $\begin{array}{l}\text { - Ceramah dan diskusi } \\
\text { tentang pengetahuan } \\
\text { pengolahan bahan alam } \\
\text { menjadi produk. } \\
\text { - Praktek tentang pembuatan } \\
\text { sabun ekstrak kulit buah } \\
\text { naga merah (Hylocereus } \\
\text { polyrhizus) }\end{array}$ & $\begin{array}{l}\text { Meningkatkan pemahaman } \\
\text { tentang cara hidup bersih dan } \\
\text { sehat, serta meningkatkan soft } \\
\text { skill siswa dalam mengolah kulit } \\
\text { buah naga merah (Hylocereus } \\
\text { polyrhizus) menjadisabun }\end{array}$ \\
\hline
\end{tabular}

\section{E. Rancangan Evaluasi}

\section{Prosedur dan Alat Evaluasi}

Untuk mengetahui apakah program yang akan dilaksanakan ini berdampak positif atau sejauh mana program ini terlaksana, sudah barang tentu dibuat suatu evaluasi yang meliput :

a) Dilakukan pre test mengenai pengetahuan tentang cara hidup bersih dan sehat, pengolahan kulit buah naga, serta cara pembuatan sabun untuk mengetahui seberapa besar pengetahuan siswa MA. Habiburrahman

b) Dilakukan pos test mengenai pengetahuan tentang cara hidup bersih dan sehat, pengolahan kulit buah naga, serta cara pembuatan sabun. Materi yang diberikan menyangkut apa yang diinformasikan saat ceramah, tanya jawab, diskusi maupun praktek

c) Selanjutnya dibandingkan antara skor pre test dan post test, sehingga akan dapat dilihat keberhasilan program yang dilakukan.

\section{Teknik Analisis Data dan Kriteria Keberhasilan Program}

Data hasil tes baik pre test maupun post test tentang pengetahuan tentang cara hidup bersih dan sehat, pengolahan kulit buah naga, serta cara pembuatan sabun.dianalisis dengan teknik analisis dekriptif.

\section{HASIL DAN PEMBAHASAN}

\section{A. Pengetahuan Siswi tentang Sabun dan Pembuatan Sabun}

Berdasarkan hasil iptek bagi masyarakat atau pengabdian yang telah dilakukan, diketahui bahwa siswa mengetahui tentang definisi dan kegunaan sabun. Namun, pada proses pembuatan sabun siswa MA. Habiburrahman belum ada yang tahu tentang bagaimana sabun dibuat, dan bahan-bahan apa saja yang diperlukan. Hal ini dapat disebabkan karena seluruh siswa merupakan siswa dengan jurusan IPS. MA. Habiburahman tidak memiliki jurusan IPA. Namun demikian, hal tersebut tidak mengurangi minat siswa dalam mengikuti program ini. Hal ini dibuktikan dengan antusias siswa dalam menjawab pertanyaan seputar sabun dan pembuatannya serta praktek pembuatan sabun secara berkelompok. 


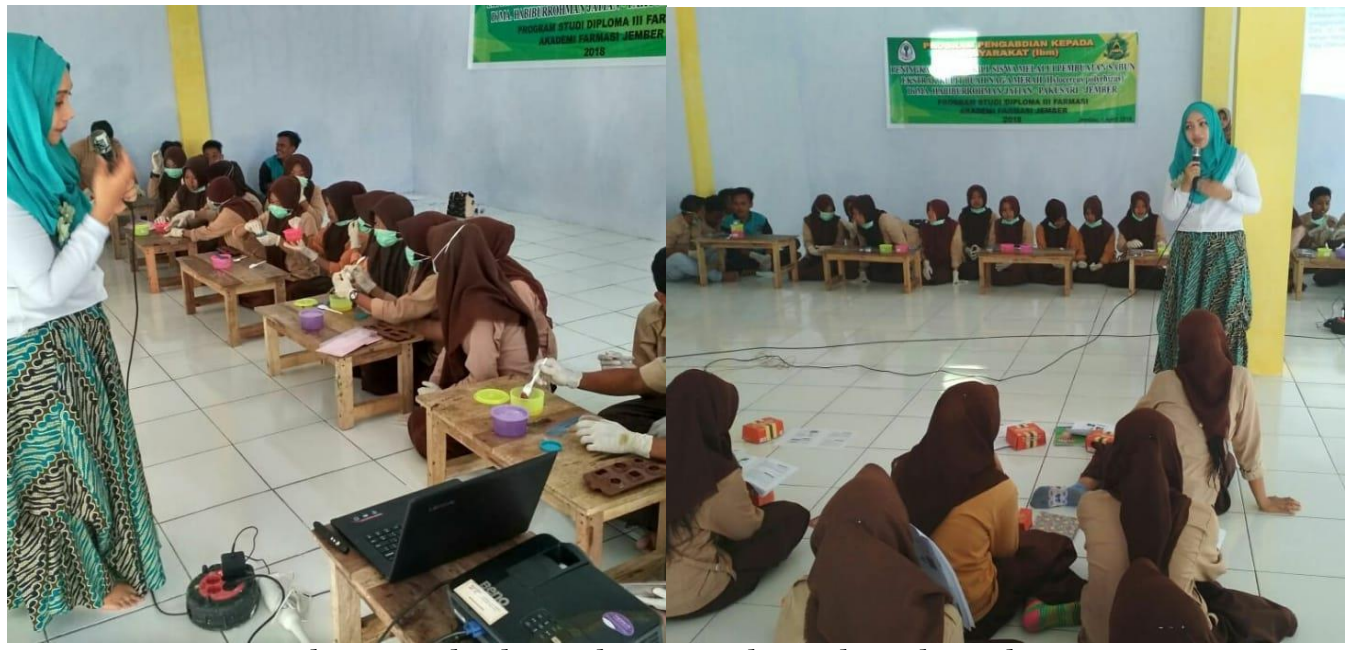

Gambar l. Praktek Pembuatan Sabun Ekstrak Buah Naga

B. Soft skill Siswa MA. Habiburrahman

Ditinjau dari segi soft skill siswa MA. Habiburrahman memang masih sangat kurang dalam hal penerapan teknologi. Hal ini dapat dipengaruhi karena lingkungan sekolah adalah lingkungan pesantren, dimana akses informasi tentang teknologi masih sangat kurang. Di lain pihak, belum adanya akses internet disekolah dan fasilitas computer yang belum lengkap juga dapat menyebabkan soft skill siswa masih kurang dalam hal teknologi.

Pengembangan Soft skill siswa masih dalam bidang pertanian dan pertukangan. Hal ini dikarenakan, siswa yang sebagian adalah santri pesantren diajarkan bagaimana bercocok tanam dan terlibat dalam pembangunan gedung pesantren.

\section{PENUTUP}

\section{A. Kesimpulan}

Berdasarkan hasil pengabdian kepada masayarakat yang telah dilakukan, dapat diambil beberapa kesimpulan, antara lain:

- Siswa MA. Habiburrahman mendapat pengetahuan baru tentang sabun dan pembuatan sabun menggunakan bahan alam sebagai bahan utama.

- Soft skill siswa meningkat di bidang teknologi melalui program ini.

\section{B. Saran}

Perlu ada tindak lanjut, dan monitoring terhadap pengembangan soft skill siswa MA. Habiburrahman di bidang penerapan teknologi yang lain, sehingga siswa memiliki bekal dan keterampilan saat lulus dari sekolah

\section{Ucapan Terimakasih}

Ucapan terimakasih penulis ucapkan kepada semua pihak yang telah membantu dalam kegiatan pengabdian kepada masyarakat ini, sehingga kegiatan dapat terlaksana dengan baik, terutama kepada:

1) Direktur Akademi Farmasi Jember

2) Ketua LPPM Akademi Farmasi Jember

3) Ketua Program studi Diploma III Farmasi Akademi Farmasi Jember 
4) Pengasuh pondok pesantren Habiburrahman Jatian-Pakusari

5) MA. Habiburrahman Jatian-Pakusari

6) Pihak-pihak lain yang telah membantu.

Semoga artikel ini dapat bermanfaat bagi penulis dan pembaca.

\section{DAFTAR PUSTAKA}

Hurlock, E.B. 1978. Perkembangan Anak.Erlangga. Jakarta.

Jaafar, Ali, R., Nazri, M., dan Khairuddin, W. 2009. Proximate Analysis of Dragon Fruit (Hylecereus polyhizus). American Journal of Applied Sciences

Satria , F,. 2011. Pengaruh Beberapa Konsentrasi Atonik Pada Pertumbuhan Setek Buah Naga Berdaging Merah ( Hylocereus costaricensis (Web) Britton \& Rose). Skripsi. Universitas Andalas. Padang

Thornburg, D.H. 1982. Development in Adolenscence. Second Edition. Brook Cole Publishing Co. California

Wu, L. C., Hsu, H. W., Chen, Y., Chiu, C. C., and Ho, Y. I. 2006. Antioxidant and Antiproliferative Activities of Red Pitaya. Food Chemistry .Volume 95. 